\title{
The Effect of Health Insurance on Institutional Delivery in Indonesia
}

\section{Pengaruh Kepemilikan Jaminan Kesehatan terhadap Persalinan pada Fasilitas Kesehatan di Indonesia}

\author{
Mazda Novi Mukhlisa*, Pujiyanto**
}

\begin{abstract}
*Center for Health Financing and Health Insurance, Ministry of Health, Jakarta, Indonesia, **Department of Health Policy and Administration, Faculty of Public Health, Universitas Indonesia, Depok, Indonesia
\end{abstract}

\begin{abstract}
In Indonesia, institutional delivery increases every year, but there are still 30\%-37\% mothers who deliver at home. Unfortunately, the increase is not in line with maternal mortality reduction, so that Indonesia does not achieve the fifth MDGs goal. To achieve Universal Health Coverage, Indonesia implements National Health Insurance (NHI). NHI integrates four types of health insurance, namely Askes/ASABRI, Jamsostek, Jamkesmas and Jamkesda. One of its benefits is maternal health services. Health insurance can address financial barriers on delivery in health facility. By using secondary data of National Basic Health Research 2013 and Village Potential 2011 data, this study aimed to analyze effect of health insurance on institutional delivery in Indonesia. Samples were 39,942 women aged $15-49$ years old who gave birth to their last child during 2010-2013. The study used econometric approach by applying probit and bivariate probit as estimation model to estimate the effect with consideration to endogeneity issue of health insurance. The results found that health insurance was likely to increase institutional delivery by $39.52 \%$. In conclusion, women who have health insurance prefer to deliver birth at health facility compared to those who do not have health insurance.
\end{abstract}

Keywords: Health insurance, institutional delivery, universal health coverage

\begin{abstract}
Abstrak
Di Indonesia, persalinan di fasilitas kesehatan mengalami peningkatan setiap tahunnya, tetapi masih terdapat sekitar $30 \%$ ibu yang bersalin di rumah. Sayangnya, peningkatan pemanfaatan pelayanan persalinan di fasilitas kesehatan tersebut tidak diimbangi dengan penurunan AKI, sehingga Indonesia tidak berhasil mencapai target MDGs. Untuk mencapai Universal Health Coverage, Indonesia mengimplementasikan program Jaminan Kesehatan Nasional (JKN). JKN mengintegrasikan empat jaminan kesehatan, yaitu Askes/ASABRI, Jamsostek, Jamkesmas, dan Jamkesda. Salah satu jaminan tersebut adalah pelayanan persalinan. Jaminan kesehatan dapat mengatasi kendala biaya pada persalinan di fasilitas kesehatan. Dengan menggunakan data Riset Kesehatan Dasar 2013 dan Potensi Desa 2011 sebagai sumber data, penelitian ini bertujuan menganalisis kepemilikan jaminan kesehatan terhadap peningkatan pemanfaatan pelayanan persalinan di fasilitas kesehatan di Indonesia. Sampel penelitian berjumlah 39.942 perempuan berusia 15-49 tahun yang melahirkan anak terakhir dalam periode waktu 2010-2013. Penelitian ini menggunakan pendekatan ekonometri dengan model estimasi probit dan bivariat probit untuk mengestimasi efek jaminan kesehatan dengan mempertimbangkan isu endogenitas pada jaminan kesehatan. Hasil penelitian menunjukkan bahwa kepemilikan jaminan kesehatan meningkatkan persalinan di fasilitas kesehatan sebesar 39,52\%. Sebagai kesimpulan, ibu yang memiliki jaminan kesehatan akan lebih memanfaatkan fasilitas kesehatan saat persalinan dibandingkan dengan ibu yang tidak memiliki jaminan kesehatan.

Kata kunci: Jaminan kesehatan, persalinan di fasilitas kesehatan, universal health coverage

How to Cite: Mukhlisa MN, Pujiyanto. The effect of health insurance on institutional delivery in Indonesia. Kesmas: National Public Health Journal. 2018; 12(3): 148-152. (doi:10.21109/kesmas.v12i3.1099)

Correspondence: Mazda Novi Mukhlisa, Center for Health Financing and Health Insurance Ministry of Health, HR Rasuna Said Street Blok X-5 Kav 4-9 Jakarta, Phone: +6221-52212297, E-mail: mazdanovi@gmail.com

Received: July $16^{\text {th }} 2016$

Revised: December $11^{\text {th }} 2017$

Accepted: December $12^{\text {th }} 2017$
\end{abstract}




\section{Introduction}

Institutional delivery plays an important role on maternal mortality rate (MMR) reduction. ${ }^{1,2}$ Global Burden of Disease study in 2015 reported that maternal mortality is in the fourth place of all mortality causes. ${ }^{3}$ Globally, MMR decreases by $45 \%$ from 380 maternal deaths per 100,000 live births in 1990 to 210 maternal deaths per 100,000 live births in 2013. MMR in developing countries is fourteen times higher than developed countries. ${ }^{4}$ MMR in Indonesia is still high that is 359 maternal deaths per 100,000 live births. ${ }^{5}$ The number does not achieve Millennium Development Goals (MDGs) target and national goal to reduce MMR at 102 per 100,000 live births. ${ }^{6}$

Institutional delivery becomes priority in Indonesia due to accessibility to equipment and supplies or due to immediate referral to secondary or tertiary health facilities if theres is any complication. Another reason is that delivery at health facility is handled by health professionals who are able to anticipate and detect signs and symptoms of complication. ${ }^{7}$ Therefore, several countries including Indonesia change their policy from delivery at health professionals to delivery at health facilities. Indonesia's target for institutional delivery is $85 \%$ delivery at health facilities by $2019 .{ }^{8}$

Globally, there is $63 \%$ institutional delivery during 2009-2013. Southeast Asian countries, such as Singapore, Brunei Darussalam, and Thailand achieve $100 \%$ for institutional delivery followed by Malaysia $(99 \%)$ and Cambodia $(83 \%) .{ }^{7}$ Based on National Basic Health Research 2013, Indonesia is at the sixth position with $70.4 \%$ delivery at health facilities. ${ }^{9}$

There are mothers who still delivered at home that are on lowest economic status. ${ }^{9}$ According to Comfort, Peterson and Hatt, ${ }^{10}$ financial barriers play an important role affecting access to maternal health services. Indonesia Demographic and Health Survey (IDHS) 2012 reported that approximately $76.6 \%$ mothers discussed childbirth costs and $15.2 \%$ mothers stated that costs became problem in health care seeking during pregnancy and childbirth. ${ }^{5}$ Therefore, costs play an important role on maternal delivery. In order to address the financial barriers, health insurance is implemented. Health insurance can address factors that affect utilization and provision of maternal health services, particularly on increasing maternal delivery at health facilities. ${ }^{10}$

By increasing access to health services, health insurance has potential to increase maternal and child outcome. A recent systematic review concluded that there was a consistent relation between health insurance and institutional delivery. 10 The review was also supported by recent studies. ${ }^{11-13}$ In Ghana, health insurance increases institutional delivery by $32.3 \% .{ }^{11}$ Another study also found that health insurance was a significant factor de- termining delivery at public health facilities and the ownership of health insurance during pregnancy tends to increase 2.5 times to deliver at health facilities. ${ }^{12}$

There were several types of health insurance in Indonesia before National Health Insurance (NHI) was implemented in 2014, which were Askes, Jamsostek, Jamkesmas, Jamkesda, private health insurance and health benefits from company. National Basic Health Research 2013 reported that $50.5 \%$ Indonesian citizens did not have health insurance. ${ }^{9}$ Jamkesmas held the greatest proportion $(28.9 \%)$. The study only covered four types of health insurance integrated in NHI namely Askes, Jamsostek, Jamkesmas (not including Jampersal) and Jamkesda.

Each health insurance has different benefit packages. One of its benefit packages is maternal delivery service. With the assurance of maternal delivery service, the use of institutional delivery is expected to increase. Thus, the expected has an impact on maternal health outcome. To analyze that health insurance has an effect on institutional delivery in Indonesia, this study was conducted.

\section{Method}

This study was a cross-sectional design using National Basic Health Research 2013 and Village Potential 2011 data. National Basic Health Research provides individual data, meanwhile Village Potential provides health facilities, health professionals and distance to health facilities data. The population was 53,765 women aged 10-54 years old. Samples were 39,942 women aged 15-49 years old who delivered last child, live birth or still birth in three years before the survey. The exclusion criteria were women who were never in labor, had private insurance and company insurance, were pregnant during interview, and had incomplete data.

The study used Grossman's Health Capital and Demand for Health theory, Principal-Agent relationship theory, and Andersen's The Behavioral Model and Access to Medical Care theory. ${ }^{14-17}$

Probit and bivariate probit (biprobit) model were used to meet the study objective. Probit model used the Equation 1 and Equation 2 where $y$ is whether women delivery at health facilities or otherwise; $C$ is whether women has health insurance or otherwise; $X$ is set variable of predisposing (age, parity, and education), enabling resources (economic status, travel time and cost to health facility, living in urban area and Java-Bali, health facilities and health professional ratio, and distance to

Equation 1.

$$
C=X_{i}^{\prime} \beta_{i}+\varepsilon_{1}
$$

Equation 2.

$$
y=X_{i}^{\prime} \beta_{i}+y C+\varepsilon_{2}
$$


health facilities), and need factor (intended pregnancy, antenatal care, pregnancy and childbirth complication). $\beta$ and $\gamma$ are parameters.

Health insurance is suspected to be endogenous because health insurance choice could be affected by unobservable characteristics. ${ }^{18}$ Endogeneity bias is likely in Equation 2. Health insurance variable is endogenous due to correlation between $\varepsilon_{1}$ and $\varepsilon_{2}(\rho \neq 0)$. Endogeneity could lead to estimator inconsistent on probit model, so that biprobit model was used, which is more consistent. ${ }^{19}$ Biprobit model was selected because dependent variable on main equation and endogenous regressor were binary. ${ }^{19,20}$ Endogeneity test in this study followed Waters, ${ }^{18}$ which is significancy of $\rho$ (rho) on biprobit model. Health insurance variable is endogenous if value of $r$ ho has $\mathrm{p}$ value less than 0.05 .

Endogeneity test of health insurance needs instrumental variable (IV) $z$ to clear relation between health insurance $(x)$ and $\varepsilon .^{21}$ Following Cercone, Pinder, Jimenez, and Briceno, 22 respondent's occupation (whether respondents were employed or otherwise) was used as instrumental variable. The appropriateness of instrumental variable was tested through Kleibergen-Paap LM statistic of under identification test and F statistic of weak identification. ${ }^{19}$

The study conducted heteroscedasticity test. The importance of heteroscedasticity test is because it could lead to bias and inconsistent result on probit and biprobit model, so that a Huber-White-Sandwich correction needed to address this issue. 18

\section{Results}

The test for potential endogeneity of health insurance confirmed that health insurance is endogenous, so that parameter estimations from probit model could lead to bias. Wald test of rho of exogeneity test was 20,1558 (p value $<0.01$ ). Therefore, estimation from biprobit model was used. Kleibergen-Paap LM statistics show that instrumental variable adequate to identify the equation $(25,665 ; \mathrm{p}$ value $<0.01)$. F test for weak identification test show that instrumental variable was not weak $(25,666 ; p$ value $<0.01)$. Instrument exogeneity could not be examined because the model only has one instrument (just identified) ${ }^{19}$. Model also has heteroskedastic issue ( $\mathrm{p}$ value $<0.01$ ) so that Huber-White-Sandwich correction was used.

Table 1 demonstrates descriptive statistics of respondent characteristics. The results showed that $72 \%$ sample had institutional delivery and $45 \%$ had health insurance. Variables on predisposing, enabling and need factors were also shown in Table 1.

Table 2 presents effect of health insurance on institutional delivery on two models. Probit model showed that health insurance increased institutional delivery by $2.97 \%$, while biprobit model increased institutional delivery by $39.52 \%$. Difference in effect also shows on other variables.

\section{Discussion}

The study used National Basic Health Research 2013 and Village Potential 2011 data, which was conducted in 33 provinces. Missing data was $0.9 \%$ due to unclear an-

Table 1. Descriptive Statistics

\begin{tabular}{|c|c|c|c|c|c|}
\hline Variables & Category & Mean & $\mathbf{9 5} \% \mathrm{CI}$ & Min & Max \\
\hline Institutional delivery & & 0.723 & $0.714-0.733$ & 0 & 1 \\
\hline Health insurance & & 0.450 & $0.441-0.459$ & 0 & 1 \\
\hline Age (years) & & 28.26 & $28.17-28.35$ & 13 & 49 \\
\hline \multirow[t]{3}{*}{ Parity } & $\geq 3$ children & 0.321 & $0.314-0.328$ & 0 & 1 \\
\hline & 2 children & 0.350 & $0.343-0.357$ & 0 & 1 \\
\hline & 1 child & 0.329 & $0.322-0.337$ & 0 & 1 \\
\hline \multirow[t]{3}{*}{ Education } & $\leq$ Elementary school & 0.365 & $0.356-0.374$ & 0 & 1 \\
\hline & Junior high school & 0.266 & $0.259-0.273$ & 0 & 1 \\
\hline & $\geq$ High school & 0.369 & $0.360-0.378$ & 0 & 1 \\
\hline \multirow[t]{5}{*}{ Economic status } & Lowest & 0.131 & $0.125-0.137$ & 0 & 1 \\
\hline & Low-middle & 0.182 & $0.176-0.188$ & 0 & 1 \\
\hline & Middle & 0.228 & $0.221-0.235$ & 0 & 1 \\
\hline & Upper-middle & 0.266 & $0.258-0.274$ & 0 & 1 \\
\hline & Highest & 0.194 & $0.187-0.201$ & 0 & 1 \\
\hline One-way travel time to health facility $<60$ minutes & & 0.929 & $0.924-0.933$ & 0 & 1 \\
\hline One-way travel cost to health facility < USD 1 & & 0.836 & $0.828-0.843$ & 0 & 1 \\
\hline Living in urban area & & 0.517 & $0.503-532$ & 0 & 1 \\
\hline Living in Java-Bali & & 0.586 & $0.573-0.599$ & 0 & 1 \\
\hline Health facility ratio & & 5.49 & $5.41-5.57$ & 0.930 & 21.25 \\
\hline Health professional ratio & & 3.23 & $3.18-3.29$ & 0.243 & 18.77 \\
\hline Long distance to health facility $(\mathrm{km})$ & & 3.12 & $3.11-3.13$ & 1.808 & 7.420 \\
\hline Intended pregnancy & & 0.850 & $0.844-0.855$ & 0 & 1 \\
\hline Complete antenatal care visit & & 0.733 & $0.725-0.740$ & 0 & 1 \\
\hline Pregnancy complication & & 0.138 & $0.132-0.144$ & 0 & 1 \\
\hline Childbirth complication & & 0.126 & $0.121-0.132$ & 0 & 1 \\
\hline
\end{tabular}


Table 2. The Effect of Health Insurance on Institutional Delivery

\begin{tabular}{|c|c|c|c|c|}
\hline \multirow{2}{*}{ Variables } & \multirow{2}{*}{$\begin{array}{l}\text { Probit-ME } \\
\text { Coeff }\end{array}$} & \multicolumn{3}{|c|}{ Biprobit-ME } \\
\hline & & SE & Coeff & SE \\
\hline \multicolumn{5}{|l|}{ Instrument variable: employment } \\
\hline Health insurance & 0.0297 **** & $(0.00591)$ & $0.3952^{* * * * *}$ & $(0.0261)$ \\
\hline Constant & $-1.901^{* * * * *}$ & $(0.106)$ & 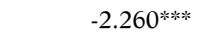 & $(0.104)$ \\
\hline Wald chi2(21) & 3519.35 & & & \\
\hline Prob > chi 2 & $<0,01$ & & & \\
\hline Pseudo R2 & 0.1747 & & & \\
\hline Log pseudolikelihood & -19443.123 & & & \\
\hline Wald chi2(42) & & & 9401.13 & \\
\hline Prob > chi 2 & & & 0,0001 & \\
\hline Log pseudolikelihood & & & -45627.721 & \\
\hline Wald test of rho $=0: \operatorname{chi} 2(1)$ dan $p$ value & & & $24.8778(<0,01)$ & \\
\hline Observations & 39,942 & & 39,942 & \\
\hline Robust standard errors in parentheses & & & & \\
\hline
\end{tabular}

swers and leap questions on age, travel costs to health facility and antenatal care visit. Endogeneity issue on health insurance variable was addressed by instrumental variable approach. Biprobit model was used to obtain consistent estimates on binary dependent and endogenous variables. ${ }^{19,20}$

The results found that proportion of institutional delivery was $72.3 \%$. The number was not far different from National Basic Health Research 2013, that was 70.4\%. ${ }^{9}$ Institutional delivery target by government is $85 \% .8$ Therefore, it is necessary to encourage the approximately $27.7 \%$ of mothers who do not deliver at health facilities.

Government, in this case Ministry of Health, has been carrying out efforts which relate to maternal health. Such efforts are placing midwife in the village in order to increase accessibility of maternal and neonatal health services; conducting Making Pregnancy Safer (MPS) Program focusing on birth attendant, complication management and unintended pregnancy prevention; carrying out Expanding Maternal and Neonatal Survival program in six provinces that have high maternal and neonatal ratio; and conducting Birth Planning and Prevention of Birth Complication with Sticker Program that involves family through community leaders.

Home delivery and traditional birth attendant (TBA) restriction become important, as the rule applied by the Philippines. The restriction give results on the low MMR and the high institutional delivery for region that implementing the restriction. ${ }^{2}$ The availability and access to maternal health services, especially maternal delivery, also contributed to the increasing institutional delivery in Bangladesh. ${ }^{1}$

The results also found that proportion of health insurance ownership was $45 \%$. The number was not far different from National Basic Health Research 2013, that was $49.5 \%$ (with addition to company and private health insurance). There are still mothers who have health insurance that do not deliver at health facility. It is assumed that there are other factors influencing the decision to deliver at health facilities, such as decision maker, and tradition and TBA interpersonal skill. ${ }^{23}$

Health insurance effect the increase in institutional delivery by $39.52 \%$. The result is in line with previous studies. ${ }^{11-13}$ Health insurance can overcome financial barrier that plays an important role in access to maternal health services. ${ }^{10}$ The increase in institutional delivery through health insurance becomes important, considering that delivery at health facilities plays an important role to reduce maternal mortality. ${ }^{1,2}$ By increasing access to health facility, health insurance has potential to increase maternal and child outcome.

The increasing of MMR reported in IDHS 2012, which was 359 deaths, compared to 228 maternal mortality per 100,000 live births. ${ }^{5}$ However, the increase could not be explained in this study. This can be caused by an increase in the volume of services and workload due to increased access, so it reduces service quality and has an impact on maternal mortality or other factors. ${ }^{10}$

For other variables, in general, the results were in line with previous studies which had positive relation to institutional delivery, except for distance to health facility and health professional ratio. Related to distance to health facility, the use of maternal health services often depends not only on distance, but also on quality of services. ${ }^{23}$ Health professional ratio has negative association to institutional delivery. The negative association is assumed due to the higher options on health professionals and rationalization of care where health professionals as agents do not initiate the demand. ${ }^{25}$ 


\section{Conclusion}

The study analyzes the effect of health insurance on institutional delivery and concludes that health insurance tends to increase delivery at health facilities by $39.52 \%$ due to increasing access to maternal delivery service. The increase is expected to give benefits to maternal outcome.

The increasing volume of services due to health insurance could give bad impact to quality of care because of the increasing workload, so it is necessary to guarantee the quality of care, particularly delivery at health facilities. Health insurance proves to improve institutional delivery, but its association with maternal mortality needs to be studied further, i.e. quality of services received by mothers. There are still mothers who have health insurance that do not deliver at health facilities. Factors behind it need to be studied further.

\section{References}

1. El Arifeen S, Hill K, Ahsan KZ, Jamil K, Nahar Q, Streatfield PK. Maternal mortality in Bangladesh: a Countdown to 2015 country case study. The Lancet. 2014; 384(9951): 1366-74. Available from: http://dx.doi.org/10.1016/S0140-6736(14)60955-7

2. Huntington D, Banzon E, Dy Recidoro Z. A systems approach to improving maternal health in the Philippines. Bulletin of the World Health Organization. 2012; 90(2): 104-10 7p. Available from: http:// www.who.int/bulletin/volumes/90/2/11-092825.pdf

3. Global Burden Disease 2013 Mortality and Causes of Death Collaborators. Global, regional, and national age-sex specific all-cause and cause-specific mortality for 240 causes of death, 1990-2013: a systematic analysis for the Global Burden of Disease Study 2013. The Lancet. 2015; 385(9963): 117-71. Available from: http://dx.doi.org/ 10.1016/S0140-6736(14)61682-2

4. World Health Organization. Trends in maternal mortality: 1990 to 2013 - Estimates by WHO, UNICEF, UNFPA, The World Bank and The United Nations Population Division. Geneva: World Health Organization; 2014.

5. Badan Pusat Statistik. Survei demografi dan kesehatan Indonesia: Laporan Pendahuluan. Jakarta: Badan Pusat Statistik; 2012. Available from: http://www.bkkbn.go.id/litbang/pusdu/Hasil Penelitian/SDKI 2012/Laporan Pendahuluan SDKI 2012.pdf

6. Kementerian Kesehatan Republik Indonesia. Rencana operasional promosi kesehatan ibu dan anak. Jakarta: Kementerian Kesehatan Republik Indonesia; 2010.

7. The United Nations Childrens' Fund. Only 1 in 2 births in Sub-Saharan Africa and South Asia are attended by a skilled provider [Internet]. Current St. 2015. Available from: http://data.unicef.org/maternalhealth/delivery-care.html

8. Kementerian Kesehatan Republik Indonesia. Rencana strategis kementerian kesehatan tahun 2015-2019. Jakarta: Kementerian Kesehatan Republik Indonesia; 2015.

9. Kementerian Kesehatan Republik Indonesia. Riset Kesehatan Dasar 2013. Jakarta: Kementerian Kesehatan Republik Indonesia; 2013.

10. Comfort AB, Peterson LA, Hatt LE. Effect of health insurance on the use and provision of maternal health services and maternal and neonatal health outcomes: A systematic review. Journal of Health, Population, and Nutrition. Bangladesh; 2013 Dec; 31(4 Suppl 2): S81-105. Available from: http://www.ncbi.nlm.nih.gov/pmc/articles/PMC4021700/

11. Brugiavini A, Pace N. Extending health insurance in Ghana?: effects of the national health insurance scheme on maternity care. Health Economics Review. 2016; 6(1): 1-10. Available from: http://dx.doi.org/10.1186/s13561-016-0083-9

12. Mubarik S, Al-hassan S, Owoo NS, Louis B. Effect of national health insurance holding on the choice of health facility for childbirth in Ghana. Science Journal of Public Health. 2016; 4(1): 26-36. Available from: http://article.sciencepublishinggroup.com/pdf/10.11648.j.sjph.201604 01.14.pdf

13. Singh K, Osei-Akoto I, Otchere F, Sodzi-Tettey S, Barrington C, Huang $\mathrm{C}$, et al. Ghana's national health insurance scheme and maternal and child health: a mixed methods study. BMC Health Service Research. 2015; 15(1): 108. Available from: http://www.biomedcentral.com/ 1472-6963/15/108

14. Grossman M. On the concept of health capital and the demand for health. The Journal of Political Economy. 1972; 80(2): 223-55. Available from: http://www.jstor.org/stable/1830580

15. Deb P, Trivedi PK. Demand for medical care by the elderly: a finite mixture approach. Journal of Applied Econometrics. 2009; 12(3): 313-36.

16. Neuman S, Neuman E, Neuman S. Agency in health-care?: are medical care-givers perfect agents? IZA Discussion Paper. 2007; (2727). Available from: http://ssrn.com/abstract=982120.

17. Andersen RM. Revisiting the behavioral model and access to medical care: does it matter? Journal of Health and Social Behavior. United States; 1995 Mar; 36(1): 1-10.

18. Waters HR. Measuring the impact of health insurance with a correction for selection bias-a case study of Ecuador. Health Economics and Econometrics. 1999/09/02 ed. 1999; 8(5): 473-83.

19. Cameron AC, Trivedi PK. Microeconometrics using Stata. Vol. 5, Stata Press books. Texas: A Stata Press Publication; 2009. 706 p. Available from: http://stata.biz/news/statanews.23.4.pd

20. Freedman DA, Sekhon JS. Endogeneity in probit response models. Political Analysis. 2010; 18(2): 138-50. Available from: https://doi.org/10.1093/pan/mpp037

21. Khandker SR, Koolwal GB, Samad HA. Handbook on impact evaluation: quantitative methods and practice. Washington, D.C.: The World Bank; 2010.

22. Cercone J, Pinder E, Jimenez JP, Briceno R. Impact of health insurance on access, use, and health status in costa rica. Escobar M-L, Griffin CC, Shaw RP, editors. The Impact of Health Insurance in Low-and MiddleIncome Countries. Washington, DC: Brookings Institution Press; 2010. p. 89-105. Available from: https://www.researchgate.net/publication/285678747

23. Gabrysch S, Campbell OMR. Still too far to walk: literature review of the determinants of delivery service use. BMC Pregnancy Childbirth. 2009 ;9: 34. Available from: https://doi.org/10.1186/1471-2393-9-34

24. MotherCare's Community Assessments. Understanding family and community behaviors and practices. MotherCare Matters. 2000; 8(3): 1-24.

25. Carlsen F, Grytten J. More physicians: improved availability or induced demand? Health Economics. England; 1998 Sep;7(6): 495-508. 